\title{
Penerapan Material Bambu Terhadap Bangunan Perpustakaan Mikro di Selaawi, Kabupaten Garut, Jawa Barat
}

\author{
Ardhiana Muhsin, Diki Kamaludin, Rafifta Ganiar F., Arvian Nashar Allam, \\ Rizka Dian Utami \\ Program Studi Arsitektur, Fakultas Arsitektur dan Desain \\ Institut Teknologi Nasional Bandung \\ Email: dade@itenas.ac.id
}

\begin{abstract}
ABSTRAK
Teknologi yang semakin canggih berdampak besar pada perkembangan dunia arsitektur masa kini. Pengembangan bahan baku material bangunan pun semakin beragam dan menghasilkan hal-hal baru. Sejalan dengan kualitas yang tersaji, tentunya akan menyebabkan dampak pada biaya yang dikeluarkan. Indonesia adalah salah satu negara dengan kekayaan bahan baku dan material tradisional yang lebih terjangkau dari segi manapun. Material yang bersifat tradisional dan konvensional semakin tenggelam oleh penggunaan beton, baja dan material modern lainnya. Bambu pada masa kini menjadi salah satu material yang jarang digunakan sebagai material utama dalam pembangunan suatu objek arsitektur. Disisi lain, material tersebut mempunyai beragam potensi baik sebagai struktur ataupun komponen pengisi pada sebuah bangunan. Penelitian ini akan membahas tentang material bambu yang akan digunakan pada sebuah bangunan perpustakaan mikro baik itu pada aspek struktur maupun penutupnya seperti dinding dan atap. Metode apa saja yang harus dilakukan terhadap material bambu agar dapat mengeluarkan potensi didalamnya dan hal apa saja yang mempengaruhi material tersebut terhadap kondisi iklim maupun keadaan sekitar lokasi pada pengerjaan perpustakaan mikro di Desa Selaawi, Kabupaten Garut, Jawa Barat.
\end{abstract}

Kata kunci : Bambu, Pengawetan, Arsitektur, Perpustakaan Mikro, Selaawi

\begin{abstract}
Increasingly sophisticated technology has a major impact on the development of the architectural world today. The development of raw materials for building materials is increasingly diverse and produces new things. In line with the quality presented, of course, it will cause an impact on the costs incurred. Indonesia is one of the countries with a wealth of raw materials and traditional materials that are more affordable from any aspect. Materials that are traditional and conventional are increasingly sinking by the use of concrete, steel and other modern materials. Bamboo today is one of the materials that rarely used as the main material in the construction of an architectural object. On the other hand, the material has a variety of potential, both as structures or filling components in a building. This research will discuss about bamboo material that will used in a micro library building both in its structural and closing aspects such as walls and roofs. What methods should be used for bamboo material in order to be able to release the potential in it and what things affect the material on the climate conditions and the situation around the location of the micro library work in Selaawi Village, Garut Regency, West Java.
\end{abstract}

Keywords : Bamboo, Curing, Architecture, Micro Library, Selaawi 


\section{PENDAHULUAN}

Bambu adalah salah satu material lokal di Indonesia yang keberadaannya memiliki sejarah panjang. Data yang ada menunjukan dari 1.200 - 1300 jenis bambu di dunia, 143 jenis atau $11 \%$ diantaranya adalah spesies asli Indonesia ${ }^{[1]}$. Angka tersebut sebenarnya telah memperlihatkan potensi bambu yang dimiliki Indonesia. Pengolahan bambu telah diterapkan pada berbagai obyek sesuai dengan kebutuhan seperti perlengkapan rumah tangga, alat musik dan sebagainya. Objek arsitektur pun menjadi salah satu karya yang dapat dikembangkan dengan menggunakan material bambu. Meskipun demikian, minimnya pengetahuan akan material ini cukup menyulitkan saat seseorang memutuskan akan menggunakan material bambu sebagai bahan utama bangunannya. Di bangku kuliah atau kampus pun, tidak semua penyelenggara pendidikan arsitektur mengenalkan konstruksi bambu pada mahasiswanya.

Desa Selaawi dipilih sebagai lokasi perencanaan dengan pertimbangan desa tersebut merupakan sentra kerajinan bambu terkenal di Jawa Barat. Sejak tahun 2017, Camat Selaawi Bapak Ridwan Effendi, SSTP., M.Si. mencanangkan pengembangan kawasan berbasis komoditas unggulan lokal (bambu) di wilayah tersebut yang diungkap dalam harian daerah "Kabar Priangan" dengan menyatakan bahwa Kecamatan Selaawi akan dijadikan sebagai kawasan "Bamboo Craft Tourism".

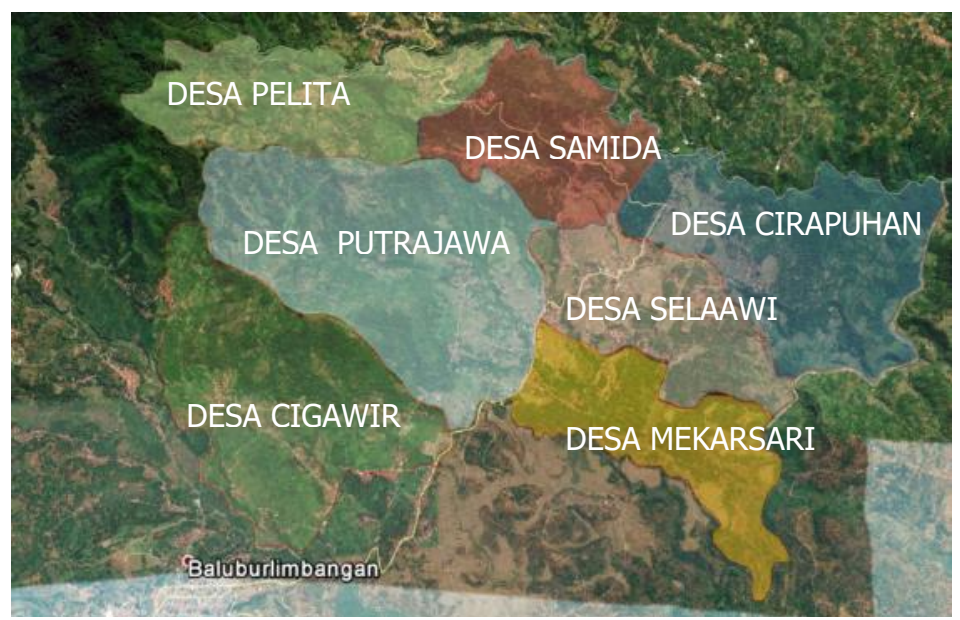

Gambar 1. Kecamatan Selaawi dan 7 desanya

Sumber: Paparan Camat Selaawi di Kemendagri, 2107

Sebagai langkah nyata, pencanangan tersebut dimulai dengan membagi peran 7 desa di wilayah Kecamatan Selaawi sebagai daerah pembibitan, budidaya bambu dan upaya konservasi air. Hal ini berarti ketersediaan bambu di daerah tersebut cukup banyak sehingga kemudian sangatlah tepat apabila bahan utama bangunan perpustakaan mikro ini terbuat dari bambu. Arsitektur bambu memang mengalami perkembangan yang sangat signifikan akhir-akhir ini dan ternyata tidak luput menjadi perhatian Camat Selaawi beserta jajarannya. Rancangan perpustakaan mikro telah disiapkan namun membangun bangunan bambu sangat berbeda dengan membangun bangunan dari material kayu atau batu bata dan semen biasa. Dimulai dari pemilihan waktu penebangan bambu yang tepat, proses pengawetan hingga konstruksinya memerlukan perhatian khusus karena tidak semua pelaksana bangunan berpengalaman menggunakan material tersebut khususnya dalam hal pengawetan dan detail sambungan bambu.

\section{TINJAUAN PUSTAKA}

Bambu merupakan material lama yang kini mulai dilirik kembali dan diyakini merupakan tumbuhan yang dapat dijadikan bahan pengganti material kayu komersial, seiring menurunnya produksi kayu komersial dengan harga yang semakin mahal ${ }^{[2]}$. Ironisnya di Indonesia, tukang atau pekerja bangunan yang mengerti tentang sambungan bambu semakin sedikit ditambah lagi dengan perkembangan 
arsitektur bambu saat ini yang menurut Widyowijatnoko dan Trautz dalam Muhsin (2018) telah mengarah ke klasifikasi engineering convensional dimana material utamanya masih menggunakan bambu utuh namun telah disisipkan rekayasa teknik untuk jenis sambungannya dan agar dapat dihitung kekuatannya ${ }^{[3]}$. Beruntung di daerah Selaawi masih banyak masyarakat yang paham tentang bambu, dimulai dari penebangan sebagai langkah awal pengadaan bahan baku bambu untuk konstruksi, pengeringan, pengawetan hingga tahap konstruksinya sehingga dalam penerapan sambungan bambu menggunakan alat sambung baru tidak terlalu menyulitkan.

\subsection{Pengadaan Bambu}

Bambu harus dipersiapkan dahulu sebelum tanggal pelaksanaan pekerjaan untuk mencari waktu yang tepat dalam menebang bambu. Menurut Surono dalam Gusti (2015), pada masyarakat Jawa perhitungan atau kearifan ini disebut Brubuh. Hal ini dimaksudkan agar pada masa penebangan kayu atau bambu memiliki kadar lignin yang rendah sehingga tidak digemari oleh serangga namun memiliki kekuatan dan kelenturan yang paling tinggi ${ }^{[4]}$. Secara prinsip, penebangan bambu lebih baik dilakukan saat musim kemarau, hanya saja perubahan cuaca yang terjadi akhir-akhir ini, mengakibatkan kejelasan musim kemarau dan musim penghujan menjadi samar. Proses selanjutnya yang masih dalam kategori pengadaan adalah pembentukan. Beberapa batang bambu perlu dibentuk atau dilengkungkan mengikuti beberapa tuntutan lengkungan yang ada pada rancangan. Metoda yang disebut bending ini memiliki beberapa cara diantaranya adalah :

\section{A. Penguapan}

Menurut Jauhar (2006), proses ini memerlukan beberapa tambahan peralatan yang harus disiapkan sebelumnya seperti tabung penguapan, pembangkit uap serta pola atau cetakan untuk melengkungkan bambunya. Lama pengerjaan kira-kira 1-2 jam tergantung diameter bambu dan ketebalan dinding bambu. Saat dikeluarkan bambu akan berada dalam kondisi plastis atau lentur dan harus segera masuk ke cetakan paling lambat 20 menit setelah dikeluarkan, setelah itu ditambah lagi sekitar 1-2 jam untuk berada dalam cetakan, barulah didapat batang bambu yang sesuai dengan keinginan ${ }^{[5]}$.

\section{B. Pembakaran/burner}

Pertama sekat-sekat bambu dihilangkan terlebih dahulu, lalu diisi pasir yang berguna sebagai penghantar panas dan mencegah agar bambu tidak retak. Jika cara pengasapan memerlukan waktu agak lama dengan menggunakan burner akan lebih cepat terutama untuk bambu berdiameter kecil antara 3-4 cm. Setelah itu baru bambu dilengkungkan dan dijepit agar tidak kembali ke bentuk asal (Gambar 2). Bagian yang dipanaskan dapat dibersihkan menggunakan lap kain basah ${ }^{[6]}$.

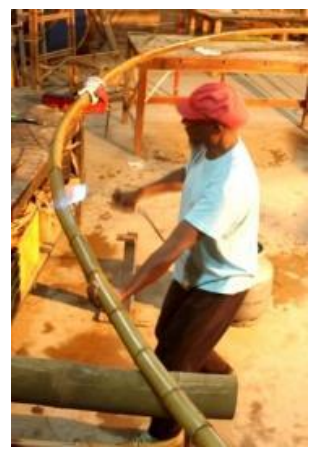

Gambar 2. Pelengkungan bambu dengan burner

Sumber : Purwito

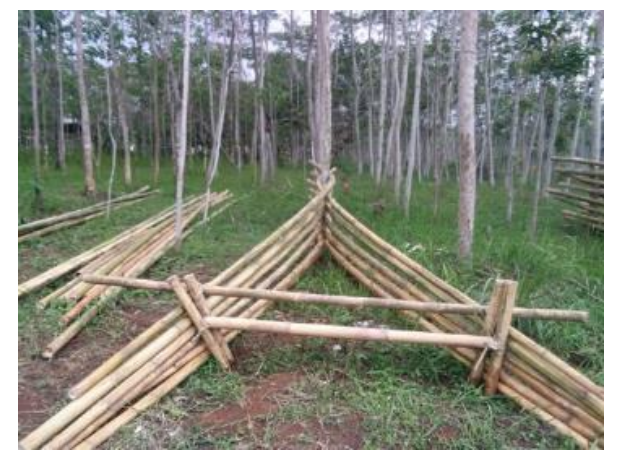

Gambar 3. Pelengkungan bambu secara manual dengan bantuan patok atau pohon di lokasi

C. Manual

Sesuai dengan namanya, cara manual ini hanya memanfaatkan kondisi kelenturan bambu selagi basah atau baru tebang. Kelengkungan bambu dapat dicapai dengan menggunakan patok atau pasak yang ditanam di alas kerja atau tanah (Gambar 3). Keuntungannya tidak memerlukan 
banyak peralatan dan dapat dipakai pada bambu berdiameter besar dengan lengkungan yang lebih lebar radiusnya.

Kondisi ini menyerupai proses bending pada bambu laminasi yang lebih dikenal dengan nama cold bending dimana bambu yang akan dilengkungkan ditempatkan pada cetakan sebagai pembentuknya ${ }^{[7]}$. Proses bending seperti ini memang memakan waktu lebih lama dibandingkan metoda lainnya. Idealnya proses bending ini memakan waktu 30 hari.

\subsection{Pengeringan}

Tahap selanjutnya adalah tahap pengeringan yang bertujuan agar muai susut bambu tidak terlalu tinggi. Umumnya bambu dikeringkan pada tempat yang teduh dan tidak kontak langsung dengan tanah guna mencegah peresapan air dari tanah. Untuk mencapai hasil yang optimal, bambu akan dibiarkan mengering selama 1-2 bulan ${ }^{[8]}$. Proses pengeringan juga dilakukan setelah pengawetan karena pada umumnya pengawetan ini menggunakan bahan berbentuk cair baik yang alami maupun yang kimiawi.

\subsection{Pengawetan}

Pekerjaan pengawetan jika memungkinkan dilakukan di sekitar lokasi pembangunan agar tidak diperlukan proses transportasi lagi. Berbagai metoda pengawetan yang umum dilakukan antara lain perendaman pada air tawar, air payau dan air laut. Proses ini berlangsung sekitar satu bulan dan dilakukan setelah proses pengeringan. Cara kedua adalah menggunakan api seperti memanggang batang bambunya. Proses ini selain mengeraskan batang bambu dapat sekaligus dipakai untuk meluruskan atau melengkungkan bambu selagi bambu dalam keadaan panas. Cara terakhir menggunakan bahan kimia dengan perendaman maupun menggunakan metoda yang terkenal dengan nama Boucherie process. Batang bambu akan dialiri larutan kimia dengan bantuan kompresi atau penekanan yang berasal dari pompa udara yang terhubung dengan container atau drum berisi larutan kimianya ${ }^{[8]}$.

\subsection{Konstruksi}

Telah dijelaskan sebelumnya bahwa penggolongan pengembangan bambu umumnya masih menggunakan bambu dalam bentuk utuh sebagai material bangunannya. Jika dahulu pada umumnya bangunan bambu ini berbentuk kecil dan ringan seperti shelter (Gambar 4a) atau rumah tinggal sederhana, pengembangan yang terjadi hampir semuanya mencoba memaksimalkan potensi yang dimiliki bambu dari kekuatan tarik, tekan dan kelenturannya sehingga bentuk sambungan dan alat sambungnya tidak lagi mengandalkan ikatan tali ijuk seperti pada umumnya. Ikatan ini bukan beresiko dan tidak kuat namun kekuatan tiap sambungannya kurang terukur atau presisi karena mengandalkan kekuatan menarik tali ijuk dari pekerjannya (Gambar 4b, 4c dan 4d).

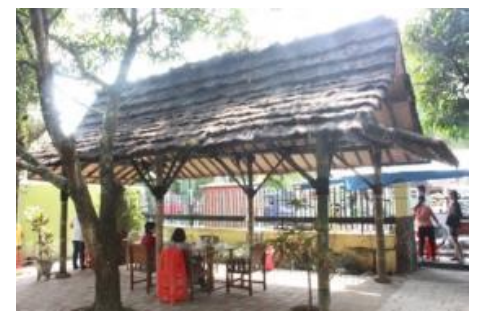

(a)

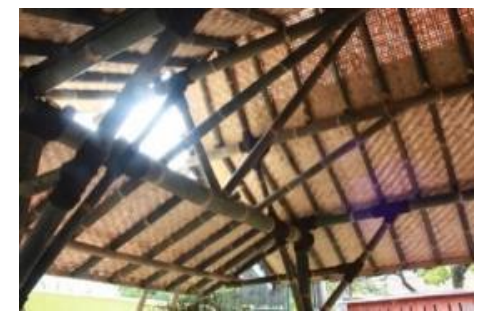

(b)

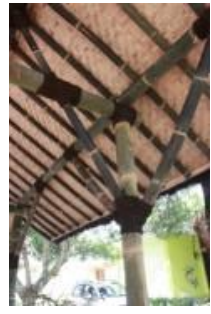

(c)

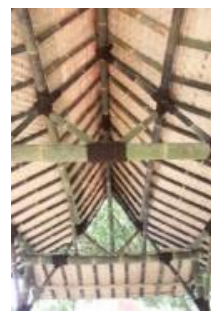

(d)

Gambar 4. Bangunan bambu dengan sambungan tradisional

Salah satu upaya yang umum dipakai dalam mengganti sambungan bambu yang berupa tali ijuk adalah dengan menggunakan mur dan baut. Sebagai contoh, beberapa rumah di desa Pengalengan, Jawa Barat yang dibangun dengan menggunakan bahan dasar bambu telah menggunakan sambungan mur baut tersebut (Gambar 5a). Apabila detail sambungan itu dicoba untuk disimulasikan melalui komputer 3 dimensi hasilnya akan terlihat seperti Gambar $5 \mathrm{~b}$ dan setelah terpotong penampangnya dapat dilihat seperti Gambar 5c. 


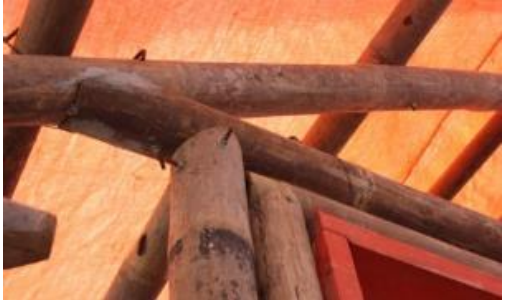

(a)

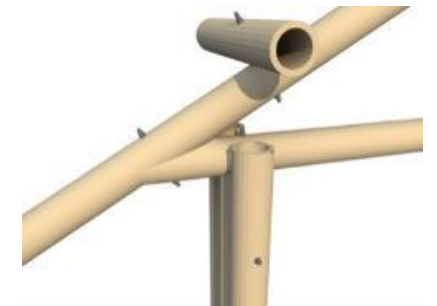

(b)

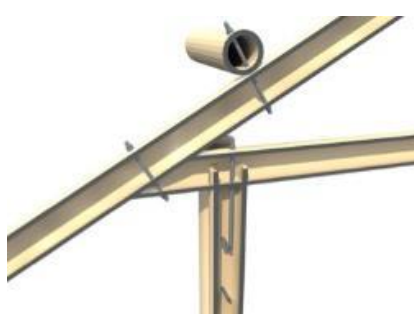

(c)

Gambar 5. Detail sambungan bambu dengan mur dan baut

\section{METODOLOGI}

Metode penelitian yang digunakan dalam kajian ini adalah metode penelitian deskriptif kualitatif. Metode deskriptif kualitatif yaitu metode penelitian yang berusaha menggambarkan objek sesuai dengan kenyataan melalui pengamatan (observasi). Penelitian dengan metode deskriptif kualitatif mempunyai langkah sebagai berikut (Gambar 6):

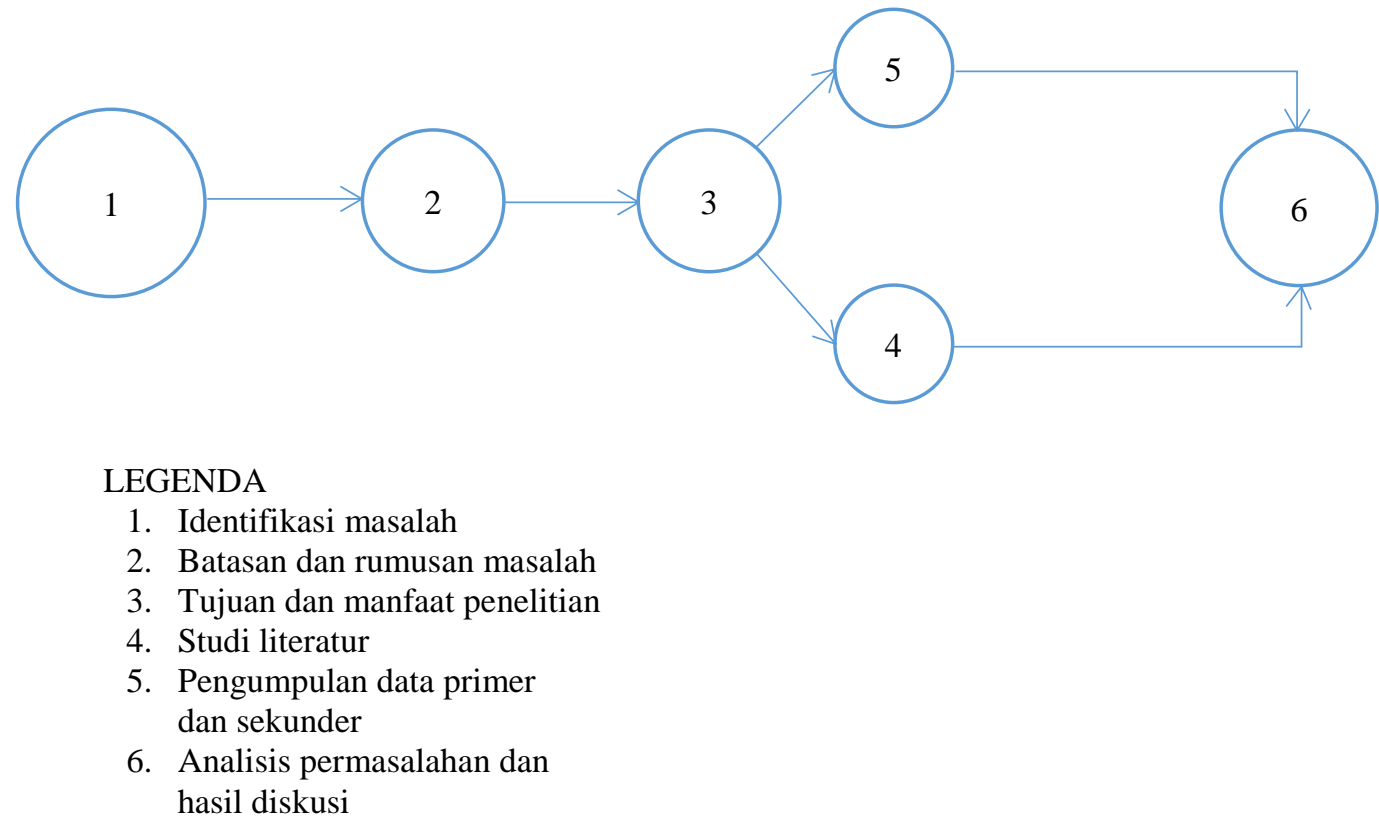

Gambar 6. Alur kerja penelitian

\section{HASIL DAN PEMBAHASAN PENERAPAN MATERIAL BAMBU}

Berlatar kondisi lokasi yang masih asri dengan pepohonan, bangunan perpustakaan mikro ini sengaja diangkat (pilotis) dengan fungsi perpustakaan sepenuhnya ada di lantai atas. Rangkaian batang-batang bambu di lantai dasar pun tampak berbaur dengan konteks alamnya. Tidak adanya dinding pembatas di lantai dasar juga menjadikan bangunan ini mudah diakses dan bersifat terbuka atau mengundang (Gambar 7). 

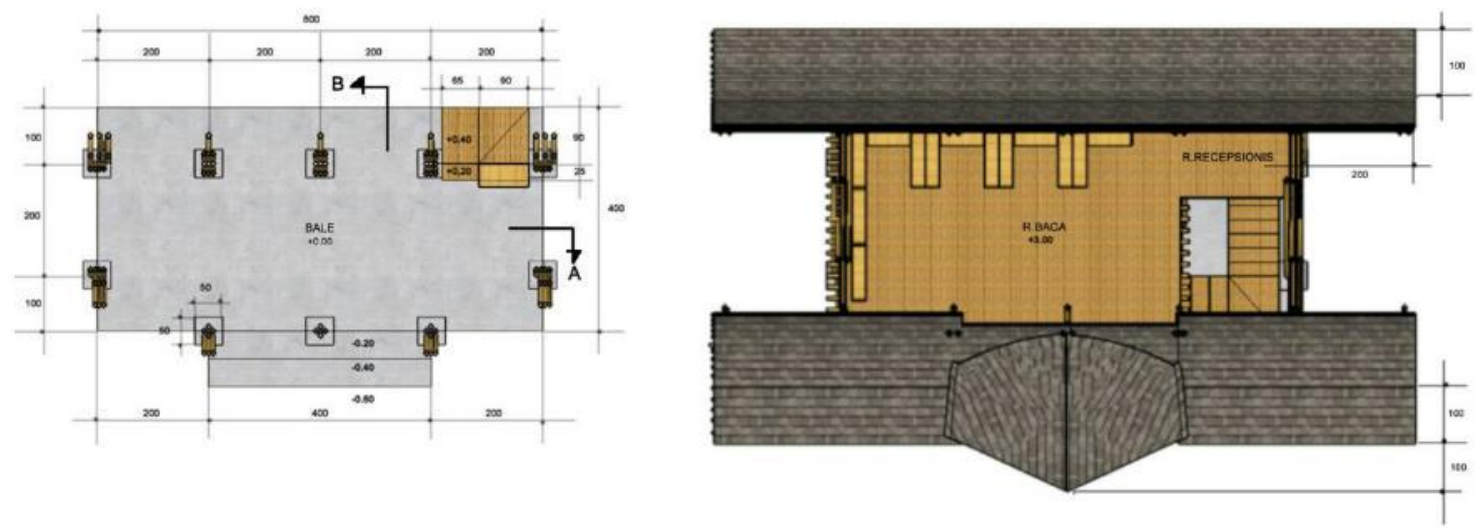

Gambar 7. Ground floor plan and upper floor plan

Sumber gambar : Himpunan Mahasiswa Arsitektur Itenas

Guna melindungi bambu dari panas dan hujan, kolom-kolom utama ditarik mundur dari tepi bangunan. Bagian sisi lainnya menempatkan kolom di tepi bangunan diantisipasi dengan teritis yang lebar sehingga diharapkan dapat mengurangi kemungkinan terpaparnya bambu terhadap cuaca secara langsung. Upaya menjaga agar bambu tetap kering tidak hanya dari air hujan namun juga dari kemungkinan meresapnya air dari tanah. Bagaimanapun bambu adalah material alam yang tidak memungkinkan untuk diekspos terhadap cuaca secara langsung. Mengatasi hal tersebut ketinggian lantai sengaja dinaikan setinggi 60 cm (Gambar 8).

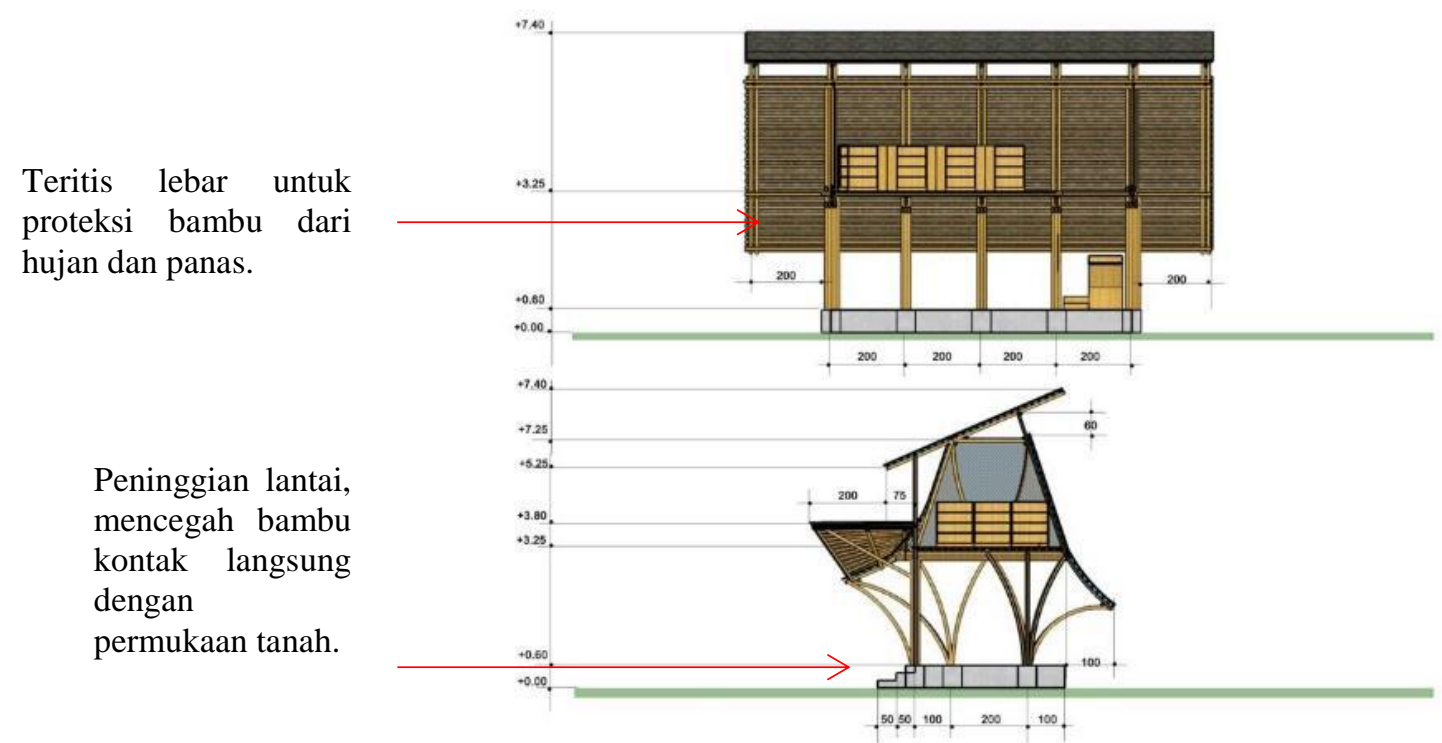

Gambar 8. Potongan melintang dan memanjang

Sumber gambar : Himpunan Mahasiswa Arsitektur Itenas

Proses pengadaan bambu untuk pekerjaan perpustakaan mikro ini telah memenuhi ketentuan masa tebangnya yaitu dipotong pada waktu musim kemarau dan berumur cukup untuk konstruksi yaitu sekitar 5 tahun. Lokasi budidaya bambu di Kecamatan Selaawi terletak di Desa Putrajawa dan Desa Pelita Asih yang lokasinya tidak jauh dari Desa Selaawi tempat dibangunnya perpustakaan mikro ini (Gambar 9). 

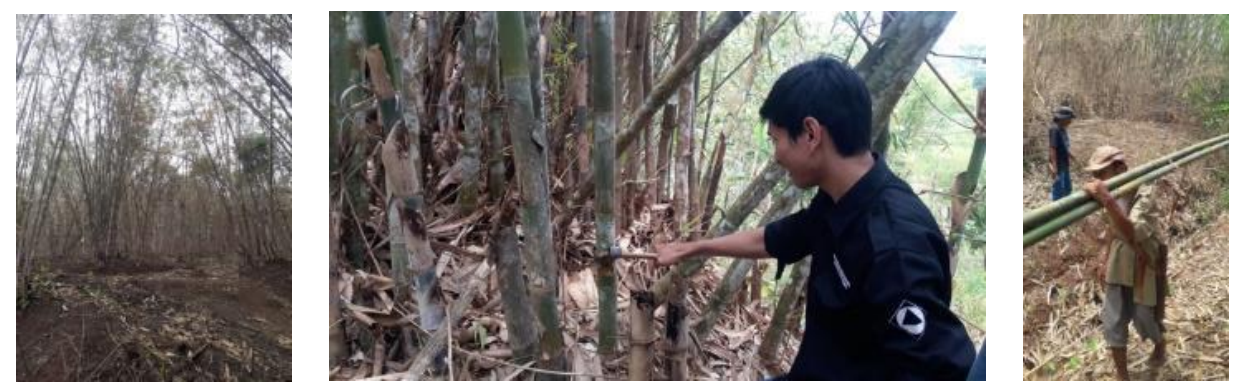

Gambar 9. Lokasi budidaya, penebangan dan pengangkutan ke transportasi darat

Sumber : Himpunan Mahasiswa Arsitektur Itenas

Pada pekerjaan bending atau pelengkungan batang bambu, dikarenakan waktu pelaksanaan telah memasuki bulan November dimana hujan sudah mulai turun, proses tersebut terpaksa dipersingkat yaitu hanya 16 hari dengan kondisi bambu awalnya yang masih berbentuk lurus. Oleh penanggungjawab pekerja di Desa Selaawi disarankan untuk segera memasang bambu tersebut sesuai posisinya setelah dilakukan pengeringan dan pengawetan, agar bambu tidak kembali ke bentuk semula. Upaya ini membuahkan hasil karena tidak didapati kendala dalam pemasangan bambu yang telah mengalami proses bending ini.
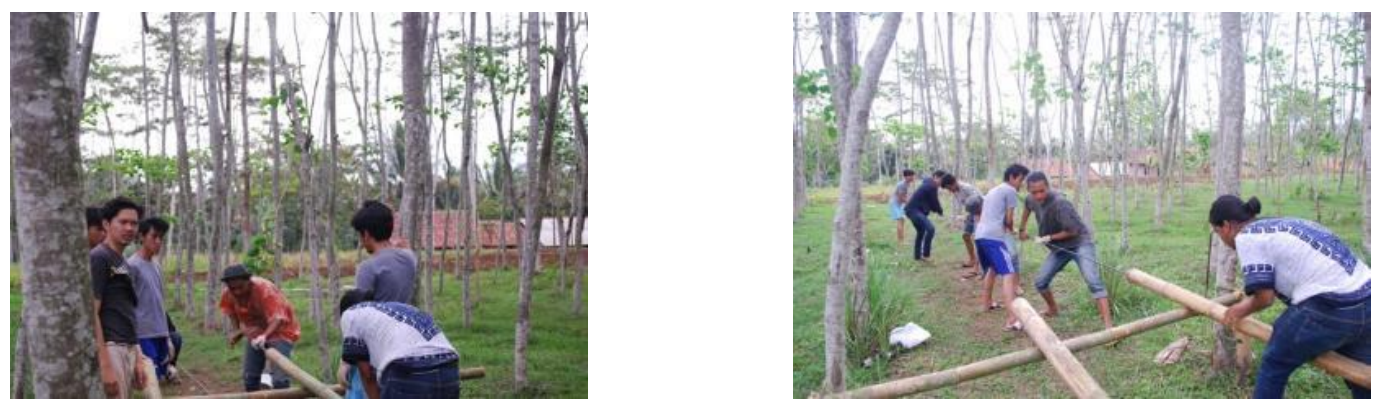

Gambar 10. Pekerjaan persiapan pengawetan

Sumber gambar : Himpunan Mahasiswa Arsitektur Itenas

Proses lain yang cukup melelahkan adalah melubangi batang-batang bambu sebelum pengawetan dimulai [10]. Buku pertama dari bambu cukup mudah untuk dilubangi namun seiring bertambah panjang batang bambu yang digunakan terutama pada posisi buku bambu mulai mendekati bagian tengah batang, pekerjaan ini semakin sulit dan memerlukan kerjasama beberapa orang untuk melakukannya. Setelah semua batang bambu siap, dimulailah proses pengawetan dengan cara perendaman. Bambu diawetkan dengan cara memberikan larutan borax atau boric acid (natrium tetraborate decahydrate) [9] sebagai salah satu bahan pengawet yang umum digunakan untuk mengawetkan bambu.
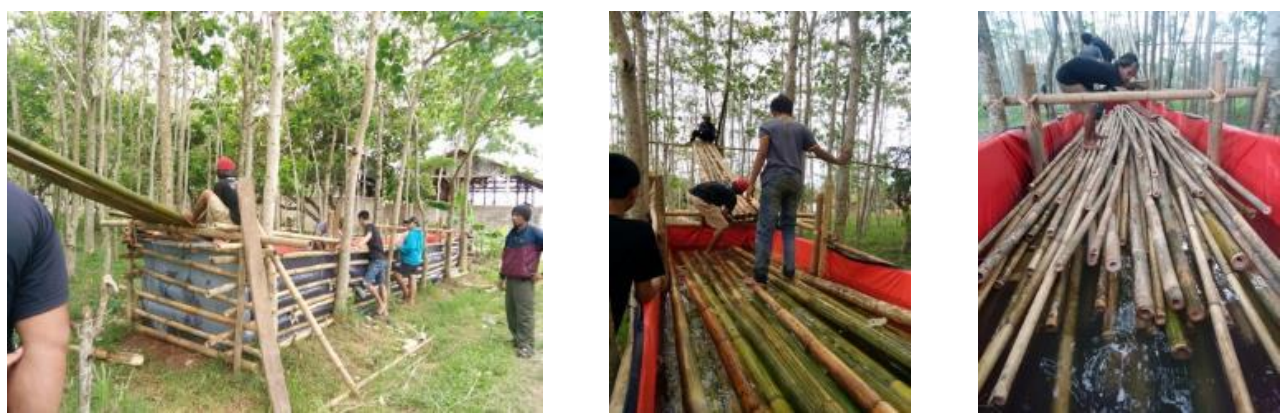

Gambar 11. Proses pengawetan bambu

Sumber : Himpunan Mahasiswa Arsitektur Itenas 
Tahap awal pembangunan membuat pondasi setempat dan diikuti dengan pondasi lajur untuk menambah ketinggian lantai. Saat pengecoran pondasi setempat angkur-angkur disiapkan yang nantinya akan dikaitkan atau disambungkan pada besi yang dipasangkan pada kolom bambu. (Gambar 12, ditandai panah merah). Detail sambungan bambu dan pondasi setempat secara ilustratif diperlihatkan pada Gambar 13.

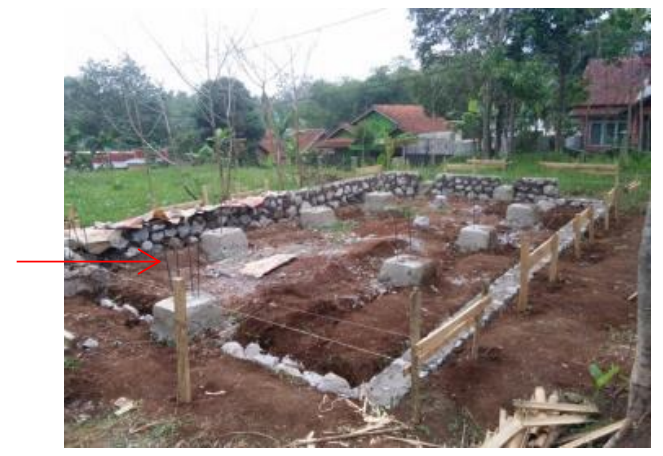

Gambar 12. Pelaksanaan Pondasi

Sumber : Himpunan Mahasiswa Arsitektur Itenas

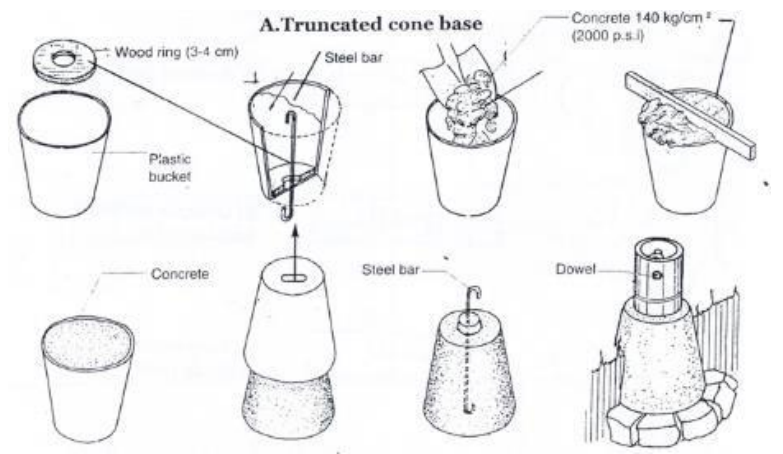

Gambar 13. Detail pondasi dan kolom bambu

Sumber : Hidalgo-Lopez, Oscar, 2003

Pekerjaan selanjutnya adalah pemasangan kolom dan balok serta rangka penahan lantai atas (Gambar 14). Guna memudahkan pelaksanaan, pertemuan penggandaan batang bambu antara kolom dan balok dibuat seperti konfigurasi pada Gambar 15. Dua batang bambu yang mengapit batang tengah dapat menerus langsung ke rangka atap sedangkan batang yang tengah akan menahan balok yang dalam hal ini berupa batang bambu rangkap 3 secara vertikal.

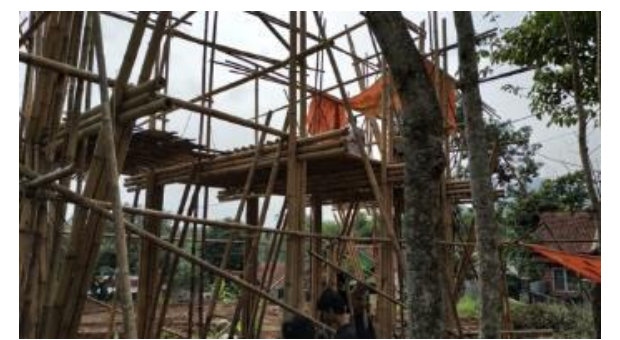

Gambar 14. Pelaksanaan kolom dan balok

Sumber : Himpunan Mahasiswa Arsitektur Itenas
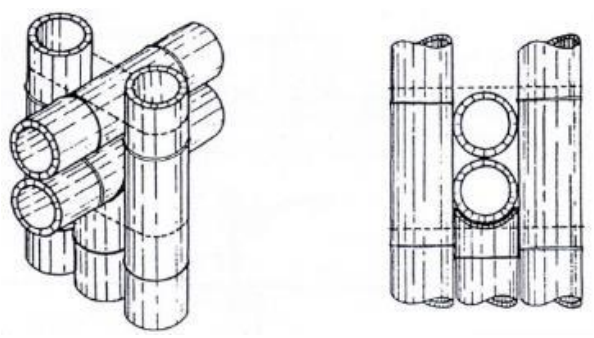

Gambar 15. Detail pondasi dan kolom bambu Sumber : Hidalgo-Lopez, Oscar, 2003

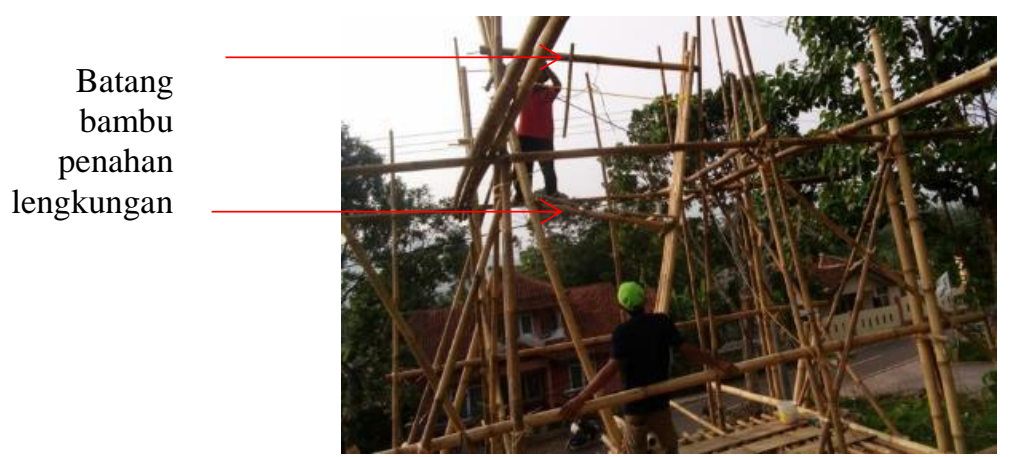

Gambar 16. Pelaksanaan konstruksi

Sumber : Himpunan Mahasiswa Arsitektur Itenas

Selama pekerjaan konstruksi, batang bambu yang dilengkungkan tetap dijaga kelengkungannya dengan bantuan batang-batang bambu (Gambar 16, ditandai dengan panah merah). Hal ini dilakukan karena durasi proses bending yang dikurangi guna mengejar waktu pelaksanaan sehingga dikhawatirkan jika tidak dibantu dengan batang-batang horizontal tersebut, kelengkungan bambu yang telah dicapai akan 
kembali ke bentuk semula. Beberapa permasalahan lain yang terjadi di lapangan selama proses pembangunan tidak dapat dihindarkan namun tentu saja selalu ada pemecahan atau kompromi agar bangunan dapat terwujud. Sebagai contoh, rancangan awal berupa tiang-tiang bambu dengan bentuk melengkung, setelah dilakukan survey di daerah penanaman bambu ternyata tidak banyak dijumpai batang bambu yang lengkungannya mendekati rancangan awal. Jika dipaksakan akan memakan waktu ataupun dana tambahan untuk mewujudkannya. Alternatif lain adalah mengganti jenis bambu yang digunakan atau mencari bambu sejenis yang berukuran lebih kecil. Berbagai kemungkinan tersebut akhirnya dikesampingkan dan diputuskan hanya berupa batang lurus saja (Gambar 17a). Jumlah batang bambu yang dipakai juga mengalami perubahan. Pada awalnya keseluruhan batang yang dipakai berjumlah 3 batang bambu namun setelah dicoba dirakit beberapa batang bambu ada yang mengalami perubahan menjadi 4 batang untuk tumpuan terluar dan yang bagian dalam dikurangi menjadi 2 batang bambu (Gambar 17b).

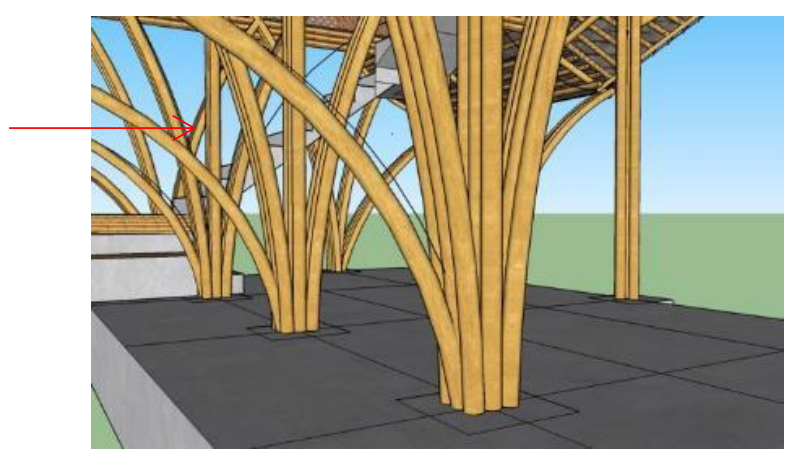

(a) (b)

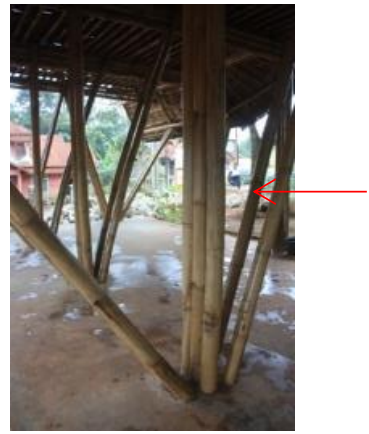

b)

Gambar 17. Penyelesaian masalah ditahap konstruksi Sumber : Himpunan Mahasiswa Arsitektur Itenas

Pekerjaan terakhir adalah penutup atap. Bagian dalam dari perpustakaan mikro ini diberi plafond yang terbuat dari bilik. Dipasang setelah sebelumnya diberi rangka plafond yang terdiri dari jajaran bambu tali dengan diameter $7 \mathrm{~cm}$ dan berjarak $40 \mathrm{~cm}$. Jarak rangka plafon ini sebenarnya variatif tergantung luasan atap sehingga saat dilihat dari dalam rangka tersebut terbagi sama besar (Gambar 18).

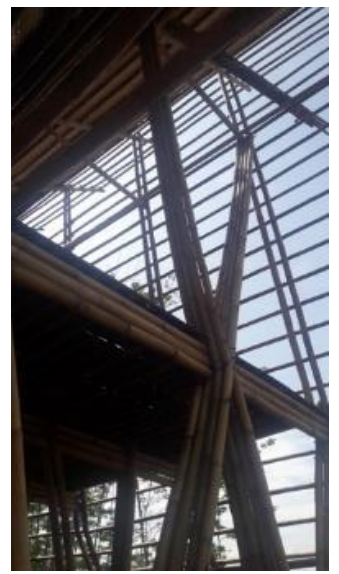

(a)

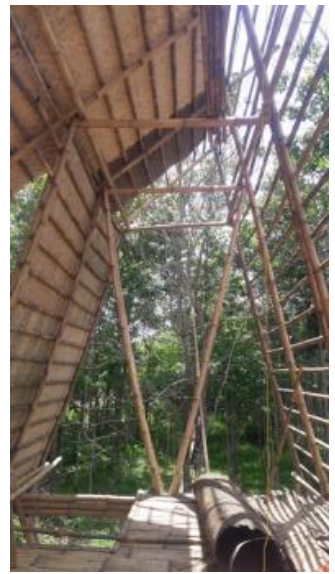

(b)

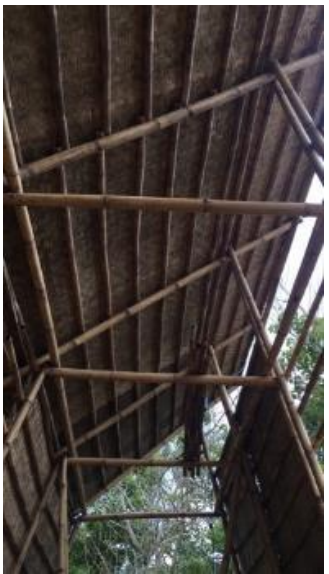

(c)

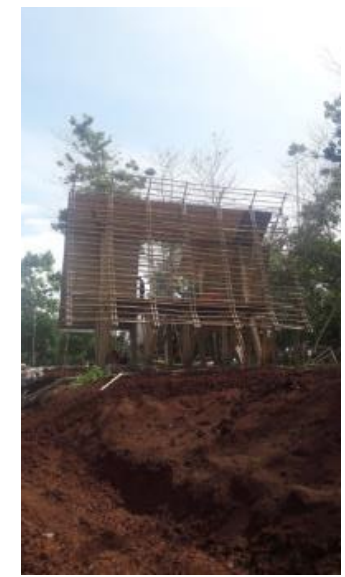

(d)

Gambar 18. Proses konstruksi

Keseluruhan sambungan pada perpustakaan mikro ini menggunakan baut dan mur yang mudah dipahami oleh pekerja bambu di daerah Selaawi yang sebelumnya belum pernah menggunakan sambungan tersebut. Gambar 19 memperlihatkan keseluruhan bangunan setelah selesai pembangunan. 


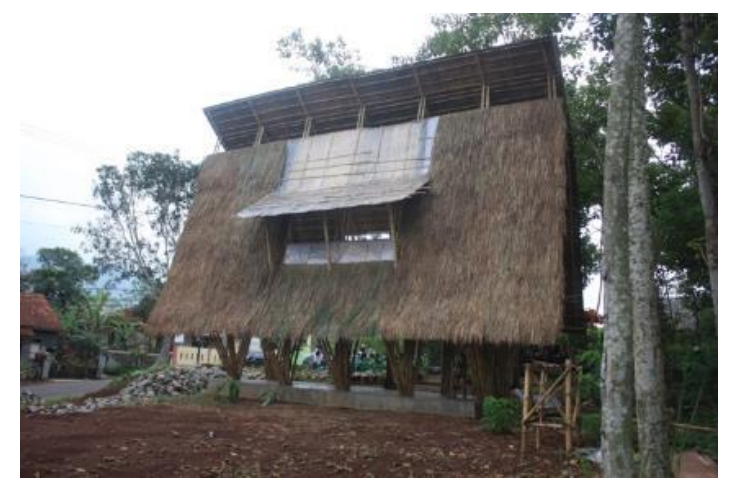

Gambar 19. Bangunan perpustakaan mikro saat selesai konstruksi

\section{SIMPULAN DAN SARAN}

Menggunakan material bambu memerlukan penanganan yang tepat dimulai dari pengadaan, pengeringan, pengawetan hingga tahap konstruksi. Perubahan alat sambung yang diterapkan berupa mur dan baut ternyata mudah dipahami oleh pekerja bambu yang sebelumnya menggunakan alat sambung tradisional atau konvensional. Bahan baku juga mudah diperoleh dan tidak memerlukan peralatan khusus. Keuntungan lainnya dengan sambungan seperti ini kekuatan bangunan dapat diperhitungkan (apabila diperlukan) seperti bangunan umum lainnya yang menggunakan kayu, baja maupun beton.

\section{UCAPAN TERIMAKASIH}

Penulis mengucapkan terimakasih kepada Bpk. Pon S. Purajatnika yang telah membantu memberikan pengarahan dalam pelaksanaan pembangunan perpustakaan mikro ini, bapak H. Saripudin selaku ketua Yayasan Selaawi Raksa Mandiri beserta stafnya yang memberikan dukungan penuh dari awal pembangunan hingga selesai serta Himpunan Mahasiswa Arsitektur Itenas yang membantu memberikan data kerja sehingga penulis dapat menyelesaikan penelitian ini.

\section{DAFTAR PUSTAKA}

[1] Widjaja, Elizabeth A. (2001). Identikit Jenis-jenis Bambu di Jawa. Bogor : Puslitbang Biologi LIPI.

[2] Nugraha, Hari. (2014). Pengolahan Material Bambu dengan Menggunakan Teknik Laminasi dan Bending untuk Produk Furniture. Widyakala, Journal of Pembangunan Jaya University. E-ISSN 2597-8624 Vol. 1. DOI : https://doi.org/10.36262/widyakala.v1i1.

[3] Muhsin, Ardhiana. (2018). Eksplorasi Material Bambu pada Bangunan Publik. Prosiding Seminar Nasional Peranan Rekayasa dan Desain dalam Percepatan Pembangunan Nasional Berkelanjutan. ISBN 978-602-53531-1-6.

[4] Gusti. (2015). Brubuh, Kearifan Masyarakat Jawa pada Lingkungan. https://ugm.ac.id/id/newsPdf/ 9697-brubuh-kearifan-masyarakat-jawa-pada-lingkungan. Diakses : 15 Maret 2020 pk. 10.18 WIB

[5] Fajrin, Jauhar. (2006). Pengembangan Alat dan Proses untuk Melengkungkan Bambu dengan Cara Penguapan. https://www.researchgate.net/ publication/275531953_Pengembangan_Alat_ dan_Proses_untuk_Melengkungkan_Bambu_dengan_Cara_Penguapan. Diakses : 3 April 2020 pk. 13.46 WIB.

[6] Guadua Bamboo. https://www.guaduabamboo.com/blog/how-to-bend-bamboo. Waktu akses : 11 Mei 2020 pk. 09.24 WIB

[7] Arsad, Effendi. (2015). Teknologi Pengolahan dan Manfaat Bambu. Jurnal Riset Industri Hasil Hutan Vol. 7 No. 1. E-ISSN : 2503-0779. Diakses : 6 Februari 2020 pk 08.00 WIB

[8] Frick, Heinz. (2004). Seri Konstruksi Arsitektur 7 Ilmu Konstruksi Bangunan Bambu, Pengantar Konstruksi Bambu. Kanisius dan Soegijapranata Press. 
[9] Adinugroho, Nurjaya. (2013)._Pengaruh Pemberian Boraks Dosis Bertingkat Terhadap Perubahan Gambaran Makroskopis dan Mikroskopis Hepar Selama 28 Hari (Studi pada Tikus Wistar). http://eprints.undip.ac.id/44112/3/NurjayaAdinugroho_G2A009136_bab2KTI.pdf. Diakses 19 April 2020 pk 15.44 WIB.

[10] Hidalgo-Lopez, Oscar. (2003). Bamboo, The Gift from the God. O. Hidalgo-Lopez Publisher, Bogota 2003. ISBN: 958334298X 